\title{
Experimental and Numerical Investigation of Injection Timing and Rail Pressure Impact on Combustion Characteristics of a Diesel Engine
}

3

4

5

6

7

8

9

10

11

12

13

14

15

16

17

18

19

20

21

22

23

24

25

26

27

28

29

30

31

32

33

34

34
Filip Jurić *, a

e-mail: filip.juric@fsb.hr

Zvonimir Petranović ${ }^{b}$

e-mail: zvonimir.petranovic@avl.com

Milan Vujanović ${ }^{\mathrm{a}}$

e-mail: milan.vujanovic@fsb.hr

Tomaž Katrašnik $^{\mathrm{c}}$
e-mail: tomaz.katrasnik@ fs.uni-lj.si

Rok Vihar ${ }^{\mathrm{c}}$

e-mail: rok.vihar@fs.uni-lj.si

Xuebin Wang ${ }^{\mathrm{d}}$

e-mail:wxb005@mail.xjtu.edu.cn

Neven Duić ${ }^{a}$

e-mail: neven.duic@fsb.hr

${ }^{a}$ Faculty of Mechanical Engineering and Naval Architecture, University of Zagreb, Ivana

Lučića 5, 10000 Zagreb, Croatia

${ }^{\mathrm{b}}$ AVL List GmbH Hans-List-Platz 1, 8020 Graz, Austria

${ }^{c}$ Faculty of Mechanical Engineering, University of Ljubljana, Aškerčeva cesta 61000

Ljubljana, Slovenia

${ }^{\mathrm{d}}$ MOE Key Laboratory of Thermo-Fluid Science and Engineering, Xi' an Jiaotong

2 University, Xi'an, Shaanxi 710049, China

3 * Corresponding author 
Cite this paper as: Jurić F, Petranović Z, Vujanović M, Katrašnik T., Vihar R, Wang X, Duić N. Experimental and Numerical Investigation of Injection Timing and Rail Pressure Impact on Combustion Characteristics of a Diesel Engine. Energy conversion and management, 2019, doi: 10.1016/j.enconman.2019.02.039.

\section{ABSTRACT}

To explore the influence of fuel injection strategy on the combustion process, the Computational Fluid Dynamics (CFD) simulations were performed, and simulation results were validated against the experimental data measured at different rail pressures and injection timings. The experiments were conducted on a diesel engine equipped with an advanced injection system that allows full control over the injection parameters. To model the combustion process of EN590 diesel fuel, two different approaches were used: the General Gas Phase Reactions (GGPR) approach and the 3-zones Extended Coherent Flame Model (ECFM$3 Z+)$. The calculated results, such as mean pressure and rate of heat release, were validated against experimental data in operating points with different injection parameters in order to prove the validity of spray and combustion sub-models. At the higher injected pressure, GGPR model showed better prediction capability in the premixed phase of combustion process, compared to the ECFM-3Z+ model. Nevertheless, in the rate-controlled phase of combustion process, ECFM-3Z+ model shows stronger diffusion of temperature field, due to the more detailed consideration of combustion diffusion phenomena in the ECFM-3Z+ governing equations. Furthermore, the results show that the rail pressure has a lower impact on the combustion process for injection timing after the Top Dead Centre (TDC). Both, single and multi-injection cases are found to be in a good agreement with the experimental data, while the GGPR approach was found to be suitable only for combustion delay determination and ECFM$3 Z+$ also for the entire combustion process.

\section{KEYWORDS}

Diesel engine, Injection, Combustion, General gas phase reactions, Coherent flame model, Spray

\section{HIGHLIGHTS}

- Numerical and experimental research of the single and multi-injection strategy

- Comparison between chemical mechanism n-heptane and combustion model ECFM-3Z+

- Better prediction of the GGPR in the premixed phase for a higher injection pressure

- Better predictions of the ECFM-3Z+ in the rate of heat release peak

- Lower impact of the rail pressure for injection timings after the TDC 
Cite this paper as: Jurić F, Petranović Z, Vujanović M, Katrašnik T., Vihar R, Wang X, Duić N. Experimental and Numerical Investigation of Injection Timing and Rail Pressure Impact on Combustion Characteristics of a Diesel Engine. Energy conversion and management, 2019, doi: 10.1016/j.enconman.2019.02.039.

\section{NOMENCLATURE}

Latin

A

$c$

$C_{D}$

$C_{P}$

$C_{1}$

$C_{2}$

$d$

$\mathrm{D}$

$E_{\mathrm{a}}$

$f$

$F_{\mathrm{d}}$

$g_{i}$

$h$

$\mathrm{H}$

$l$

m

$\dot{m}$

M

$n_{\text {cycl }}$

$n_{n h}$

$p$

$q$

$q^{t}$

$r$

$R$

$\mathrm{S}$

$t$

$T$

$u, v$

V
Description

Unit

Constant in Arrhenius law

Species concentration

$\mathrm{mol} \mathrm{m}^{-3}$

Drag coefficient

Cunningham correction factor

WAVE breakup model constant 1

WAVE breakup model constant 2

Droplet diameter

$\mathrm{m}$

Effective diffusion coefficient

Activation energy

$\mathrm{m}^{2} \mathrm{~s}^{-1}$

$\mathrm{J} \mathrm{kg}^{-1}$

Frequency

$\mathrm{Hz}$

Drag force

$\mathrm{N}$

Cartesian component of the force vector

Enthalpy

Total enthalpy interfacial exchange term

Length of the nozzle

Mass

Mass flow

Molar mass

Number of cylinders

Number of nozzle holes

Pressure

Heat flux

Turbulent heat flux

Droplet radius

Ideal gas constant

Source of extensive property

Time

Velocity

Volume
$\mathrm{Pa}$

S

K

$\mathrm{m} \mathrm{s}^{-1}$

$\mathrm{m} \mathrm{s}^{-2}$

$\mathrm{kJ} \mathrm{kg}^{-1}$

$\mathrm{kJ} \mathrm{kg}^{-1}$

$\mathrm{m}$

$\mathrm{kg}$

$\mathrm{kg} \mathrm{s}^{-1}$

$\mathrm{kg} \mathrm{kmol}^{-1}$

$\mathrm{W} \mathrm{m}{ }^{-2}$

$\mathrm{W} \mathrm{m} \mathrm{m}^{-2}$

$\mathrm{m}$

$\mathrm{J}(\mathrm{mol} \mathrm{K})^{-1}$

$\mathrm{m}^{3}$ 
Cite this paper as: Jurić F, Petranović Z, Vujanović M, Katrašnik T., Vihar R, Wang X, Duić N. Experimental and Numerical Investigation of Injection Timing and Rail Pressure Impact on Combustion Characteristics of a Diesel Engine. Energy conversion and management, 2019, doi: 10.1016/j.enconman.2019.02.039.

$\begin{array}{lll}w & \text { Molecular weight of species k } & \mathrm{kg} \mathrm{kmol}^{-1} \\ x & \text { Cartesian coordinates } & \mathrm{m} \\ Y & \text { Mass fraction } & \end{array}$

$\begin{array}{lll}\text { Greek } & \text { Description } & \text { Unit } \\ \alpha & \text { Volume fraction } & \\ \beta & \text { Coefficient in Arrhenius law } & \mathrm{rad} \\ \gamma & \text { Half outer cone angle } & \\ \Gamma & \text { Diffusion coefficient } & \mathrm{m} \\ \lambda_{\mathrm{w}} & \text { Wavelength } & \mathrm{Pa} \mathrm{s} \\ \mu^{\mathrm{t}} & \text { Turbulent viscosity } & \mathrm{kg} \mathrm{m} \mathrm{m}^{-3} \\ \rho & \text { Density } & \mathrm{s} \\ \tau_{\mathrm{a}} & \text { Breakup time } & \\ \varphi & \text { Extensive property of general conservation equation } & \\ \omega & \text { Reaction rate } & \mathrm{s} \\ \Omega & \text { Wave growth rate } & \end{array}$

Despite the increasingly strict emissions standards, diesel fuel continues to be the primary energy source for the transportation systems [1]. The main reason for that is diesel engine higher thermal efficiency when comparing to the spark ignition ones, especially for heavy load transport [2]. Currently, the consumption of diesel fuel in the transportation sector is three times larger than gasoline, with recorded increasing trend [3] which can be addressed to higher conversion efficiency, higher specific power output, and better reliability of diesel engines [4]. Therefore, the researches in more efficient engine operation are flourishing [5].

The overall energy efficiency of diesel engines regarding fuel consumption and pollutant emissions highly depends on the spray and combustion processes. Fuel evaporation, vapour interaction with the surrounding gases, and subsequent combustion are directly determined with the fuel injection strategy [6]. Therefore, to contribute to the diesel engine efficiency 81 increase, the in-depth understanding of evaporation and combustion process is of great importance [7]. To examine the impact of the injection system on the combustion process, it is common to couple the CFD analyses with the experimental research [8]. This approach is capable of getting a validated insight of physical and chemical phenomena inside the cylinder such as temperature field, evaporated fuel, flame zones, emission concentrations, and spray 
Cite this paper as: Jurić F, Petranović Z, Vujanović M, Katrašnik T., Vihar R, Wang X, Duić N. Experimental and Numerical Investigation of Injection Timing and Rail Pressure Impact on Combustion Characteristics of a Diesel Engine. Energy conversion and management, 2019, doi: 10.1016/j.enconman.2019.02.039.

cloud shape [9]. With such insight and the in-depth understanding of combustion and spray processes, it could be possible to achieve the reduction of emission formation [10]. For example, in [11] the authors combined experimental and numerical approach to determine the possible enhancements of diesel engine design and operation. A detailed investigation of the multi-injection strategy was conducted in [12], where CFD analysis showed the capabilities to model the low-temperature combustion in order to achieve higher efficiency, lower nitric oxides, and lower soot emissions. In [13], the authors showed the possibilities to achieve the higher thermal efficiency of a dual fuel engine by optimising the fuel injection strategy. It is known that the fuel consumption efficiency and pollutant emissions depend on the injection system parameters, piston geometry parameters, and conditions inside the combustion chamber [14]. For example, in [15] the authors presented the optimization process of piston design. A similar procedure can be adopted for injection timing research and influence of fuel injection strategy on the combustion process, as shown in [8] and [16]. Recent numerical researches of diesel engines also focused on the swirl motion [17] and engine cooling influence [18] on the combustion and emission formation processes. Regarding the injection timing, several experimental investigations were carried out to show the influence of multi-injection strategies on the in-cylinder pressure [19]. Most of the experimental studies have been hitherto conducted with a constant injection parameters [20]. Similar experimental investigations for different percentage of animal fat in diesel fuel blends were carried out to quantify their impact on incylinder pressure and emissions [21].

The experimental measurements in this research were conducted on an upgraded fourcylinder PSA Diesel 1.6 HDi engine that allows full control over the fuel injection parameters. The multi-injection strategy features the separate pilot and main injections which results in reducing the emissions and engine combustion noise [22]. The Pilot Injection (PI) is used to produce a small amount of vapour that ignites and increases the mean in-cylinder temperature [23]. At later crank angle positions, the Main Injection (MI) follows. In this research, the EN590 diesel fuel that features low sulphur content and it is characterised by a cetane number 51 was used to power the experimental engine [24]. To model the combustion process with the GGPR approach, the n-heptane $\left(\mathrm{C}_{7} \mathrm{H}_{16}\right)$ chemical mechanism was employed [25]. This mechanism contains skeletal general gas phase reactions of chemical species, where the chemical kinetic was described with the CHEMKIN tabulation [26]. Since the chemical and physical properties of the diesel fuel EN590 in experiments were different from n-heptane, fluid intensive properties were taken from the EN590 database [27]. Such an approach is commonly used in the literature [28].

The main novelty of this research is an analysis of ECFM-3Z+ and GGPR combustion modelling approaches coupled with the experimental investigation on the real industrial IC engine including both single injection and multi-injection strategy. To the best of our 
Cite this paper as: Jurić F, Petranović Z, Vujanović M, Katrašnik T., Vihar R, Wang X, Duić N. Experimental and Numerical Investigation of Injection Timing and Rail Pressure Impact on Combustion Characteristics of a Diesel Engine. Energy conversion and management, 2019, doi: 10.1016/j.enconman.2019.02.039.

knowledge, the comparison between two combustion modelling approaches together with the experimental research was examined on this scale for the first time. Apart from validating the results on both single and multi-injection system in a real industrial diesel engine, the impacts of injection parameters like injection timing and rail pressure were also analysed with the combination of experimental research and numerical simulations. Furthermore, the research revealed some specific point during the analysis. The combustion process in the Diesel engines is mainly dominated by the chemistry, which effects in the better agreement of the GGPR results with the experimental data in the premixed stage of the combustion. While the ECFM$3 Z+$ shows a better prediction in the late combustion due to the better description of the mixing time that depends on the turbulence quantities (turbulence kinetic energy and turbulence dissipation rate). The presented combination of experimental research and numerical simulations can be successfully used for further investigation of both single injection and multiinjection parameters that influence the combustion process. Finally, the calculated results such as the mean pressure and the rate of heat release (ROHR) were compared with the experimental data.

\section{MATHEMATICAL MODEL}

All simulations were performed using the Reynolds-Averaged Navier-Stokes (RANS) equation approach. For the turbulence modelling, the $k-\zeta-f$ turbulence model was employed [29].

\subsection{Spray modelling}

CFD simulations were performed by using the Euler Lagrangian (EL) modelling approach considering processes such as fuel atomization, droplet evaporation, and vapour combustion [30]. The definition of the EL spray approach is that the two-phase flow is described for a gas phase and a liquid fuel in a different manner. The gas phase is treated as a continuum while the liquid fuel is treated as discrete parcels. The continuum assumption is based on the conservation equations for the finite control volume approach where the fluid flow is divided into a selected number of control volumes [31].

The discrete parcels are tracked through the flow field by using the Lagrangian mechanics. In this research, authors considered only the drag force occurring due to the high relative velocities between the interacting phases. The parcel trajectories are described as:

$$
F_{\mathrm{d} i}=m_{\mathrm{p}} \frac{d u_{\mathrm{p} i}}{d t}
$$

where the drag force, $F_{\mathrm{d} i}$, is calculated by employing the Schiller Neumann drag law [32]: 
Cite this paper as: Jurić F, Petranović Z, Vujanović M, Katrašnik T., Vihar R, Wang X, Duić N. Experimental and Numerical Investigation of Injection Timing and Rail Pressure Impact on Combustion Characteristics of a Diesel Engine. Energy conversion and management, 2019, doi: 10.1016/j.enconman.2019.02.039.

$$
F_{\mathrm{d} i}=0.5 \pi r^{2} \rho C_{D} u_{i}^{2}
$$

where the drag coefficient $C_{D}$ is calculated depending on Reynolds number, $\operatorname{Re}$ [33]:

$$
C_{D}=\left\{\begin{array}{cl}
\frac{24}{R e C_{p}}\left(1+0.15 R e^{0.687}\right) & R e<10^{3} \\
\frac{0.44}{C_{p}} & R e \geq 10^{3}
\end{array} .\right.
$$

163

164

165

166

167

168

169

170

171

172

173

174

175

176

177

178

179

180

181

182

183

184

185

186

187

188

189

In Equation (3), the $C_{p}$ is the experimentally determined Cunningham correction factor [33]. When the fuel injection starts the liquid jet disintegrates into smaller droplets. To model the spray disintegration process, the WAVE breakup model was employed [34]. The assumptions of this model are the spherical shape of liquid droplets and proportionality of the wavelength of surface wave and growth of initial perturbations. Thus, the radius of a disintegrated droplet, $r_{\text {stable }}$ can be expressed as:

$$
r_{\text {stable }}=\lambda_{w} \mathrm{C}_{1}
$$

where $C_{1}$ is the model constant, and $\lambda_{w}$ is the wavelength of the fastest growing wave on the parcel surface. The rate of parcel radius reduction is calculated according to:

$$
\frac{d r}{d t}=-\frac{\left(r-r_{\text {stable }}\right)}{\tau_{a}}
$$

where the modelled breakup time $\tau_{a}$ is defined as:

$$
\tau_{a}=\frac{3.726 r C_{2}}{\lambda_{w} \Omega}
$$

The term $C_{2}$ in Equation (6) is the constant used to tune the droplet breakup time. The wavelength $\lambda_{w}$ and the wave growth rate $\Omega$, occurring in Equation (6) depend on the local flow properties, as discussed in [34].

\subsection{Combustion modelling}

The combustion process is modelled by using two different approaches; General Gas Phase Reactions (GGPR) and combustion model ECFM-3Z+ [27]. The first approach uses various chemical mechanisms described through species chemical reactions and by using the Arrhenius 
Cite this paper as: Jurić F, Petranović Z, Vujanović M, Katrašnik T., Vihar R, Wang X, Duić N. Experimental and Numerical Investigation of Injection Timing and Rail Pressure Impact on Combustion Characteristics of a Diesel Engine. Energy conversion and management, 2019, doi: 10.1016/j.enconman.2019.02.039.

law. On the other hand, the ECFM-3Z+ model is one of the coherent flame approaches suitable for the modelling of the combustion process in diesel engines.

\subsubsection{General gas phase reactions}

The combustion process can be modelled by using chemical kinetics. With such an approach, a higher modelling accuracy can be achieved but with increased computational effort, comparing to the commonly used combustion models. In this work, the skeletal chemical mechanism for $\mathrm{n}$-heptane $\left(\mathrm{C}_{7} \mathrm{H}_{16}\right)$, described with 46 chemical species and 182 chemical reactions is employed [25]. To obtain the mass fraction of each chemical species in the gaseous phase, an additional transport equation is solved. The calculation of the source term in the species transport equation is calculated as:

$$
\omega=A \cdot T^{\beta} \cdot e^{-\frac{E_{a}}{R T}}
$$

where the constants A, $\beta$ and $E_{a}$ are given in the CHEMKIN tabulation for each reaction and are derived from the experimental investigation [25]. The FIRE ${ }^{\mathrm{TM}}$ solver provides the input data of species mass fractions and their thermodynamic data in each cell and calculates their reaction rates based on the perfectly stirred $0 \mathrm{D}$ reactor model. The chemical species can originate in chemical reactions as products, but they also can be reactants. If the chemical species is a reactant, it will be modelled as a sink in the corresponding transport equation:

$$
\frac{\partial}{\partial t}\left(\rho y_{x}\right)+\frac{\partial}{\partial x_{i}}\left(\rho \tilde{u}_{i} y_{x}\right)=\frac{\partial}{\partial x_{i}}\left(\Gamma_{x} \frac{\partial y_{x}}{\partial x_{i}}\right)+S_{x}
$$

The species source term $S_{x}$ in Equation (8) is expressed as a difference between all forward and backwards reactions, considering the concentration of chemical species in these reactions:

$$
\mathrm{S}_{x}=\frac{d c_{i}}{d t} \cdot M_{i}=\sum_{n=1}^{f} \omega_{n, f} \cdot c_{n, f} \cdot c_{o x y}-\sum_{n=1}^{b} \omega_{n, b} \cdot c_{n, b} \cdot c_{r e d}
$$

where the index $f$ is the number of forwarding chemical reaction, in which the chemical species are generated, and index $b$ is the number of backwards chemical reactions. In Equation (9), $c_{o x y}$ denotes the molar concentration of the oxidizer and $c_{r e d}$ denotes the molar concentration of the redactor, and $c_{n, f}$ and $c_{n, b}$ represent molar concentrations of all species that participate in forward chemical reactions, i.e. backwards chemical reactions. The heat released from each reaction is summed up and it is included in the energy conservation equation. 
Cite this paper as: Jurić F, Petranović Z, Vujanović M, Katrašnik T., Vihar R, Wang X, Duić N. Experimental and Numerical Investigation of Injection Timing and Rail Pressure Impact on Combustion Characteristics of a Diesel Engine. Energy conversion and management, 2019, doi: 10.1016/j.enconman.2019.02.039.

For describing turbulence-chemistry interaction, Probability Density Function (PDF) approach was considered in this work. Probability Density Function in this model is based on the presumed Gaussian Probability Density Function. The temperature T is assumed to be the sum of mean temperature and temperature variance:

$$
T=\bar{T}+x \sqrt{\overline{T^{\prime} T^{\prime}}}
$$

where the probability density function of $\mathrm{x}$ is the standard Gaussian function $p(x)$. The mean value of temperature function can be calculated as approximate quadrature formula:

$$
\overline{f(T)} \approx \sum_{k=1}^{n}\left(\bar{T}+x_{k} \sqrt{\overline{T^{\prime} T^{\prime}}}\right) c_{k}
$$

where the $c_{k}$ is a coefficient in each node $x_{k}$ calculated using the formula:

$$
c_{k}=\int_{-\infty}^{\infty}\left(\prod_{j \neq k} \frac{x-x_{j}}{x_{k}-x_{j}}\right)^{2} p(x) d x
$$

Finally, temperature variance is calculated solving its transport equation with its correction factors:

$$
\frac{\partial}{\partial t}\left(\rho \overline{T^{\prime} T^{\prime}}\right)+\frac{\partial}{\partial x_{i}}\left(\rho \tilde{u}_{i} \overline{T^{\prime} T^{\prime}}\right)=\frac{\partial}{\partial x_{i}}\left(\frac{20}{17} \mu_{t} \frac{\partial \overline{T^{\prime T \prime}}}{\partial x_{i}}\right)+2.86 \mu_{t}\left(\frac{\partial \bar{T}}{\partial x_{i}}\right)^{2}-2 \rho \frac{\varepsilon}{k} \overline{T^{\prime} T^{\prime}} .
$$

\subsubsection{Three-zones Extended Coherent Flame Model}

The 3-zones Extended Coherent Flame Model (ECFM-3Z+) is one of the coherent flame models suitable for modelling the combustion process in diesel engines. This model has a decoupled treatment of chemistry and turbulence, which makes it an attractive solution for combustion modelling [35]. Besides the standard species transport equations, the ECFM-3Z+ solves additionally transport equations of 11 chemical species: $\mathrm{O}_{2}, \mathrm{~N}_{2}, \mathrm{CO}_{2}, \mathrm{CO}, \mathrm{H}_{2}, \mathrm{H}_{2} \mathrm{O}, \mathrm{O}$, $\mathrm{H}, \mathrm{N}, \mathrm{OH}$ and $\mathrm{NO}$ in each cell [27]:

$$
\frac{\partial \bar{\rho} \tilde{y}_{x}}{\partial t}+\frac{\partial \bar{\rho} \widetilde{u}_{i} \tilde{y}_{x}}{\partial x_{i}}-\frac{\partial}{\partial x_{i}}\left(\left(\frac{\mu}{S c}+\frac{\mu_{t}}{S c_{t}}\right) \frac{\partial \tilde{y}_{x}}{\partial x_{i}}\right)=\overline{\dot{\omega}_{x}}
$$


Cite this paper as: Jurić F, Petranović Z, Vujanović M, Katrašnik T., Vihar R, Wang X, Duić N. Experimental and Numerical Investigation of Injection Timing and Rail Pressure Impact on Combustion Characteristics of a Diesel Engine. Energy conversion and management, 2019, doi: 10.1016/j.enconman.2019.02.039.

where $\tilde{y}_{x}$ is the averaged mass fraction of species $x$ and $\overline{\omega_{x}}$ is the corresponding combustion source term. Furthermore, three transport equation for the fuel mass fraction $y_{f u}$, mixture fraction $f$ and residual gas mass $g$ have to be solved [27]:

$$
\frac{\partial}{\partial t}(\rho g)+\frac{\partial}{\partial x_{i}}\left(\rho \tilde{u}_{i} g\right)=\frac{\partial}{\partial x_{i}}\left(\Gamma_{g} \frac{\partial g}{\partial x_{i}}\right) \text {. }
$$

$$
\frac{\partial}{\partial t}\left(\rho y_{f u}\right)+\frac{\partial}{\partial x_{i}}\left(\rho \tilde{u}_{i} y_{f u}\right)=\frac{\partial}{\partial x_{i}}\left(\Gamma_{f u} \frac{\partial y_{f u}}{\partial x_{i}}\right)+S_{f u},
$$$$
\frac{\partial}{\partial t}(\rho f)+\frac{\partial}{\partial x_{i}}\left(\rho \tilde{u}_{i} f\right)=\frac{\partial}{\partial x_{i}}\left(\Gamma_{f} \frac{\partial f}{\partial x_{i}}\right),
$$

The fuel fraction is divided into two variables: fuel mass fraction in the fresh gases $\tilde{y}_{u . f}$ and fuel mass fraction in burnt gases. Where the fuel mass fraction in the fresh gases $\tilde{y}_{u \text {.f. }}$ is calculated from the transport equation:

$$
\frac{\partial \bar{\rho} \tilde{y}_{u . f .}}{\partial t}+\frac{\partial \bar{\rho} \tilde{u}_{i} \tilde{y}_{u . f .}}{\partial x_{i}}=\frac{\partial}{\partial x_{i}}\left[\left(\frac{\mu}{s c}+\frac{\mu_{t}}{S c_{t}}\right) \frac{\partial \tilde{y}_{u . f .}}{\partial x_{i}}\right]+\bar{\rho} \tilde{\hat{S}}_{u . f .}+\overline{\omega_{\dot{u} . f .}},
$$

and the fuel mass fraction in burnt gases is calculated as the difference between the fuel mass fraction $y_{f u}$ and fuel mass fraction in the fresh gases $\tilde{y}_{\text {u.f. }}$. Additionally, the mixing of evaporated fuel with fresh air is modelled with the transport equations for the unmixed fuel and the unmixed oxygen. The unmixed fuel $\tilde{y}_{f}$ and unmixed oxygen $\tilde{y}_{a .02}$ are calculated as:

$$
\frac{\partial \bar{\rho} \tilde{y}_{f}}{\partial t}+\frac{\partial \bar{\rho} \tilde{u}_{i} \tilde{y}_{f}}{\partial x_{i}}-\frac{\partial}{\partial x_{i}}\left(\frac{\mu}{S c} \frac{\partial \bar{\rho} \tilde{y}_{f}}{\partial x_{i}}\right) \frac{\partial \tilde{y}_{f}}{\partial x_{i}}=\bar{\rho} \tilde{S}_{f}-\frac{1}{\tau_{m}} \tilde{y}_{f}\left(1-\tilde{y}_{f} \frac{\bar{\rho} M_{m i x}}{\overline{\rho_{u} M_{f}}}\right),
$$

where the source terms depend on the mixing time $\tau_{m}$ which considers turbulence quantities, and is defined as:

$$
\frac{\partial \bar{\rho} \tilde{y}_{a .02}}{\partial t}+\frac{\partial \bar{\rho} \tilde{\tau}_{\iota} \tilde{y}_{a .02}}{\partial x_{i}}-\frac{\partial}{\partial x_{i}}\left(\frac{\mu}{S c} \frac{\partial \bar{\rho} \tilde{y}_{a .02}}{\partial x_{i}}\right) \frac{\partial \tilde{y}_{a .02}}{\partial x_{i}}=\bar{\rho} \tilde{S}_{f}-\frac{1}{\tau_{m}} \tilde{y}_{a .02}\left(1-\frac{\tilde{y} a .02}{\tilde{y}_{\infty .02}} \frac{\bar{\rho} M_{m i x}}{\overline{\rho_{u} M_{f}}}\right),
$$

$$
\text { and is defined as: }
$$

$\frac{1}{\tau_{m}}=\beta \frac{\varepsilon}{k}$,

where the $\beta$ is a model factor with the value 1 . 
Cite this paper as: Jurić F, Petranović Z, Vujanović M, Katrašnik T., Vihar R, Wang X, Duić N. Experimental and Numerical Investigation of Injection Timing and Rail Pressure Impact on Combustion Characteristics of a Diesel Engine. Energy conversion and management, 2019, doi: 10.1016/j.enconman.2019.02.039.

\section{EXPERIMENTAL SETUP}

The experimental investigation was performed on a modified four-cylinder, four-stroke, turbocharged 1.6 litre PSA light-duty Diesel engine. Main characteristics of the engine are given in Table 1. For this study, the engine was reworked in a way that one of the cylinders was thermodynamically separated along with the entire gas path and fuel supply system, as presented in Figure 1. This allowed a fully flexible control over thermodynamic states in the intake (IM) and exhaust manifolds (EM), and injection parameters of the observed cylinder, which allow for exploring a wide range of operating conditions in precisely controlled variation studies. For that purpose, the intake air for separated cylinder was externally supplied with compressed air from laboratory high pressure distribution system using a pressure regulator. The exhaust manifold pressure of the separated cylinder was regulated by a backpressure valve in the exhaust system of the cylinder. Remaining three cylinders, that were not the part of this study, were using original turbocharger and were controlled by an original electronic control unit (ECU).

\begin{tabular}{ll}
\hline Engine & PSA DV6 ATED4 \\
\hline Cylinders & 4, inline \\
Displacement & $1560 \mathrm{~cm}^{3}$ \\
Bore & $75 \mathrm{~mm}$ \\
Stroke & $88.3 \mathrm{~mm}$ \\
Compression ratio & $18: 1$ \\
Cooling system & Water cooled \\
\hline
\end{tabular}

Table 1 Engine characteristics.

301

Full control over the injection timing, fuel quantity, and injection pressure was performed with injection control system (National Instruments, Drivven system), which controlled energizing characteristics of the injectors, as well as the operation of separated common rail high-pressure pump to ensure a full and precise control over the injection parameters of the analysed cylinder. The main characteristics of the fuel injection system are given in Table 2 .

The engine was coupled with a Zöllner B-350AC eddy-current dynamometer controlled by Kristel, Seibt \& Co control system KS ADAC. In-cylinder pressure was measured with a calibrated piezo-electric pressure transducer (AVL GH14D) in combination with charge amplifier AVL MICROIFEM, connected to 16-bit, 4 channel National Instruments dataacquisition system with a maximum sampling frequency of 1 sample per second per channel (MS/s/ch). An optical shaft encoder Kistler CAM UNIT Type 2613B provided an external trigger and an external clock at 0.1 crank angle degree $\left({ }^{\circ} \mathrm{CA}\right)$ for data acquisition and injection 
Cite this paper as: Jurić F, Petranović Z, Vujanović M, Katrašnik T., Vihar R, Wang X, Duić N. Experimental and Numerical Investigation of Injection Timing and Rail Pressure Impact on Combustion Characteristics of a Diesel Engine. Energy conversion and management, 2019, doi: 10.1016/j.enconman.2019.02.039.

314 control system. Top dead centre (TDC) was determined by capacitive sensor COM Type 2653.

315 The maximum uncertainty of pressure measurement, which combines the uncertainties of 316 pressure transducer, charge amplifier and data acquisition system, is $0.31 \%$ and maximum 317 uncertainty of pressure measurement corresponding to crank angle was therefore $0.96 \%$.

\begin{tabular}{ll}
\hline Fuel injection system & Common rail \\
\hline Injector type & Solenoid \\
Number of holes & 6 \\
Hole diameter & $0.115 \mathrm{~mm}$ \\
Spray angle & $149^{\circ}$ \\
Nozzle diameter at hole centre position & $2.05 \mathrm{~mm}$ \\
\hline
\end{tabular}

320

Table 2 Fuel injection system characteristics.

Data acquisition and injection control embedded system was based on National Instruments cRIO 9024 processing unit and 9114 chassis. The same system was used for indication of in-cylinder pressure traces and engine control. Fuel mass flow was measured with AVL 730 gravimetric balance while intake airflow was measured with Coriolis flowmeter Micro Motion, model F025.

Representative pressure trace was generated by averaging 100 consecutive pressure cycles in selected operational point at a sampling resolution of $0.1^{\circ} \mathrm{CA}$. Representative incylinder pressure trace was generated through a two steps approach. First, 100 consecutive cycles of the individual operating point were averaged to eliminate Cycle-to-Cycle Variations (CCV) due to signal noise [36]. Second, pressure oscillations in the combustion chamber that occur as a result of partial auto-ignition of the fuel were eliminated by applying low-pass finite impulse response (FIR) filter [37]. The representative pressure trace was then used as an input for the ROHR analysis that was performed with the AVL Burn ${ }^{\mathrm{TM}}$ software [38]. The employed software tool is based on detailed OD thermodynamic equations considering variable gas properties determined via the NASA polynomials and relevant partial derivatives of nonperfect gases as well as the compressibility factor. Detailed equations for OD ROHR calculation, which are based on mass, enthalpy and species conservation, are presented in [39]. 
Cite this paper as: Jurić F, Petranović Z, Vujanović M, Katrašnik T., Vihar R, Wang X, Duić N. Experimental and Numerical Investigation of Injection Timing and Rail Pressure Impact on Combustion Characteristics of a Diesel Engine. Energy conversion and management, 2019, doi: 10.1016/j.enconman.2019.02.039.

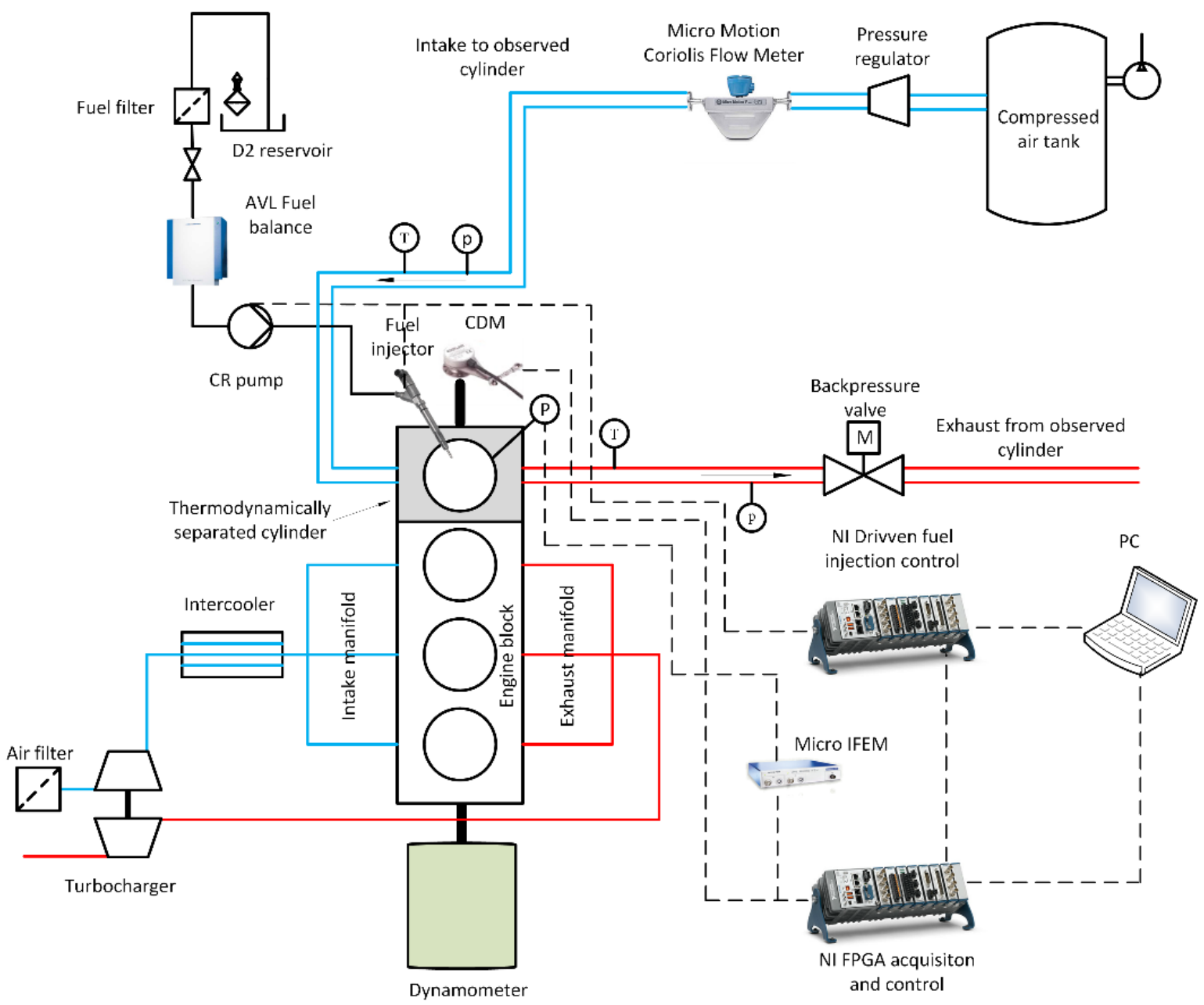

Figure 1 Scheme of the experimental system

341 To obtain the geometrical parameters, three-dimensional (3D) scan of the $\omega$-shaped 342 piston geometry was performed. The experiments were performed at $15001 / \mathrm{min}$ while varying 343 start of energizing (SOE), energizing duration (ED), and rail pressure (RP) keeping constant 344 indicated mean effective pressure (IMEP). The characteristics of the observed engine operating 345 points are shown in Table 3.

\begin{tabular}{ccccccccc}
\hline \#Case & $\begin{array}{c}\text { En. Speed [rpm] } \\
{[1 / \mathrm{min}]}\end{array}$ & $\begin{array}{c}\text { p_IM } \\
{[\mathrm{bar}]}\end{array}$ & $\begin{array}{c}\text { Fuel flow } \\
{[\mathrm{kg} / \mathrm{h}]}\end{array}$ & $\begin{array}{c}\text { IMEP } \\
{[\mathrm{bar}]}\end{array}$ & $\begin{array}{c}\text { Air flow } \\
{[\mathrm{kg} / \mathrm{h}]}\end{array}$ & $\begin{array}{c}\text { RP } \\
{[\mathrm{bar}]}\end{array}$ & $\begin{array}{c}\text { SOE } \\
{\left[{ }^{\circ} \mathrm{CA}\right]}\end{array}$ & $\begin{array}{c}\text { ED } \\
{[\mu \mathrm{s}]}\end{array}$ \\
\hline$a$ & 1500 & 1,40 & 0,42 & 4,17 & 17,93 & 600 & 705 & 545 \\
$b$ & 1500 & 1,40 & 0,43 & 4,22 & 17,84 & 600 & 715 & 540 \\
$c$ & 1500 & 1,40 & 0,45 & 4,18 & 17,57 & 600 & 725 & 570 \\
$d$ & 1500 & 1,40 & 0,42 & 4,17 & 17,31 & 1200 & 705 & 365 \\
$e$ & 1500 & 1,40 & 0,41 & 4,23 & 17,28 & 1200 & 715 & 356 \\
$f$ & 1500 & 1,40 & 0,42 & 4,26 & 17,11 & 1200 & 725 & 370 \\
\hline
\end{tabular}

347 Table 3 Operating single injection points with corresponding engine operating parameters 
Cite this paper as: Jurić F, Petranović Z, Vujanović M, Katrašnik T., Vihar R, Wang X, Duić N. Experimental and Numerical Investigation of Injection Timing and Rail Pressure Impact on Combustion Characteristics of a Diesel Engine. Energy conversion and management, 2019, doi: 10.1016/j.enconman.2019.02.039.

349 In order to prove high predictability of the proposed modelling approach, also the more 350 demanding case with two separate injections (PI and MI) at the same rotation speed was 351 observed. For this operating point different parameters, such as the start of the pilot injection 352 energizing (SOPE), the start of main injection energizing (SOME), duration of pilot injection 353 (PED), and the duration of the main injection (MED) are shown in Table 4.

354

\begin{tabular}{ccccccccccc}
\hline \#Case & $\begin{array}{c}\text { En. Speed [rpm] } \\
{[1 / \mathrm{min}]}\end{array}$ & $\begin{array}{c}\text { p_IM } \\
{[\mathrm{bar}]}\end{array}$ & $\begin{array}{c}\text { Fuel flow } \\
{[\mathrm{kg} / \mathrm{h}]}\end{array}$ & $\begin{array}{c}\text { IMEP } \\
{[\mathrm{bar}]}\end{array}$ & $\begin{array}{c}\text { Air flow } \\
{[\mathrm{kg} / \mathrm{h}]}\end{array}$ & $\begin{array}{c}\text { RP } \\
{[\mathrm{bar}]}\end{array}$ & $\begin{array}{c}\text { SOPE } \\
{\left[{ }^{\circ} \mathrm{CA}\right]}\end{array}$ & $\begin{array}{c}\text { PED } \\
{[\mu \mathrm{s}]}\end{array}$ & $\begin{array}{c}\text { SOME } \\
{\left[{ }^{\circ} \mathrm{CA}\right]}\end{array}$ & $\begin{array}{c}\text { MED } \\
{[\mu \mathrm{s}]}\end{array}$ \\
\hline$g$ & 1499,6 & 1,1702 & 2,42 & 4,8862 & 78,26 & 700 & 695 & 240 & 714 & 545 \\
\hline
\end{tabular}

355 Table 4 Operating multi-injection point with corresponding engine operating parameters

\section{NUMERICAL SETUP}

Numerical simulations were performed by using the commercial 3D CFD software AVL FIRE $^{\text {TM }}$ for the closed valve period. The control volume mesh is covering $1 / 6^{\text {th }}$ of the cylinder

360 bowl due to the 6 symmetrically distributed nozzle holes. Therefore, the injection from only 361 one nozzle hole was considered. The computational domain was generated by using the AVL 362 FIRETM ESE DIESEL tool [27]. Initially, the piston geometry was scanned and the moving 363 computational mesh was generated. The generated mesh contains 32500 control volumes at the 364 Top Dead Centre (TDC), and 56412 control volumes in the Bottom Dead Centre (BDC). In order to correctly describe the fluid flow interaction with the wall, a two-cell thick boundary was created at the wall boundary selections declared in Table 5. The mesh movement was based on the interpolation between two meshes of identical topology, while the rezoning procedure was considered by exchanging meshes with same outer boundaries and with a different number of control volumes [40]. The mesh dependency study was conducted generating two additional moving meshes of same block structure with approximately 1.5 and 2 times more cells. The simulations with the same setup were run for all three meshes, where the obtained results were different for less than $1 \%$. From that comparison, the presented mesh was selected for all calculations in this work, since it is capturing all the necessary flow features with satisfying accuracy in less computational time. All meshes in the mesh dependency study are generated with the first grid boundary nodes at approximately $1 \mathrm{~mm}$ from the wall, at $y+$ value around 30-35 which fits the log-law profile for turbulent flows, according to literature [41]. 
Cite this paper as: Jurić F, Petranović Z, Vujanović M, Katrašnik T., Vihar R, Wang X, Duić N. Experimental and Numerical Investigation of Injection Timing and Rail Pressure Impact on Combustion Characteristics of a Diesel Engine. Energy conversion and management, 2019, doi: 10.1016/j.enconman.2019.02.039.

378

379

380

381

382

383

384

385

386

387

388

389

390

391

392

393

394

395

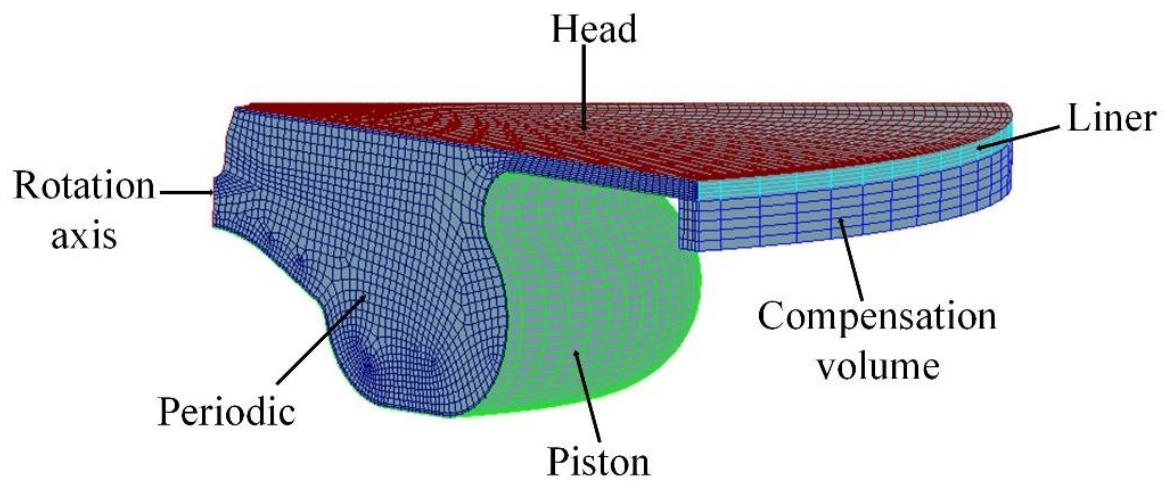

Figure 2 Computational domain at the top dead centre

The piston selection was defined as a moving part which resulted in deformation of specific computational cells. Therefore, the mesh was rezoned several times to satisfy pre-defined conditions of cell aspect ratio and orthogonality. The details regarding the boundary conditions are shown in Table 5. The engine head temperature was controlled by cooling water while cooling oil controlled the piston temperature. Those surfaces were assumed as isothermal boundary conditions with temperatures corresponding to the experimentally measured values.

The cylinder geometry was assumed to be symmetric around the cylinder axis, and therefore the segment cut boundary was defined as the periodic inlet/outlet boundary condition. In order to compensate the geometric irregularities, the compensation volume was generated and it was defined as an adiabatic boundary condition. Mesh dependency tests were performed on three meshes with different cell size and with same block structure geometry where for all three meshes the converged results were matching. Therefore, the mesh with the lowest number of cells was selected for further calculations in order to save computational time and still provide reliable results.

\begin{tabular}{lll}
\hline Boundary condition & Type & Specific condition \\
\hline Piston & Mesh movement wall & Temperature $560 \mathrm{~K}$ \\
Head & Fixed wall & Temperature $530 \mathrm{~K}$ \\
Liner & Fixed wall & Temperature from $360 \mathrm{~K}$ to \\
& & $450 \mathrm{~K}$ \\
Cylinder axis & Symmetry & \\
Compensation volume wall & Mesh movement wall & Adiabatic \\
Periodic segment cut & Periodic inlet/outlet & Boundary connection \\
\hline
\end{tabular}


Cite this paper as: Jurić F, Petranović Z, Vujanović M, Katrašnik T., Vihar R, Wang X, Duić N. Experimental and Numerical Investigation of Injection Timing and Rail Pressure Impact on Combustion Characteristics of a Diesel Engine. Energy conversion and management, 2019, doi: 10.1016/j.enconman.2019.02.039.

402

Figure 3 shows the computational domain symmetry plane cut section, while the red rectangle shows a detailed view of the orifice refinement section that was generated in order to achieve more stable and robust calculations.

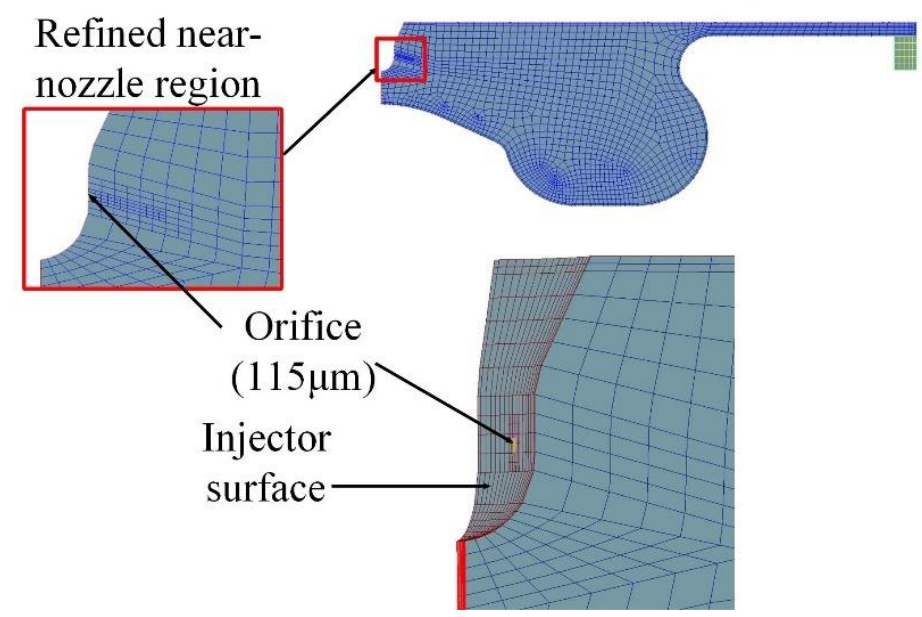

Figure 3 Computational domain with details on near-nozzle region refinement (left)

The initial pressure, temperature and gas composition were defined according to the available experimental data. The initial velocity field inside the cylinder was defined with swirl value of $4000 \mathrm{~min}^{-1}$ around the $\mathrm{z}$-axis.

In both combustion modelling approaches, at the crank angle positions characteristic for the injection and combustion process, the smallest time step was defined as $0.1^{\circ} \mathrm{CA}$, while the largest time step size of $1^{\circ} \mathrm{CA}$ was defined during the compression stroke. The CourantFriedrichs-Lewy (CFL) criteria with a maximum CFL number of 1 was used to determine the instant time step and the time integration was done by the first order Euler implicit scheme. For turbulence and energy transport equations, the first order upwind differencing scheme was used, while for the momentum equation, the MINMOD Relaxed scheme was employed [27]. The convergence criteria were satisfied when normalised energy, momentum and pressure residuals reached a value lower than $10^{-4}$. The pressure-velocity coupling was performed by employing the SIMPLE algorithm for solving the pressure correction equation.

\subsection{Injection parameters and spray setup}

Fuel mass injected in each cycle is calculated from the total fuel consumption measured at the fuel tank. The connection is obtained from the mass conservation law, and can be expressed as:

$$
m_{\text {cycle }}=\frac{2 \cdot \dot{m}_{f t}}{f \cdot n_{c y c l} \cdot n_{n h}}
$$


Cite this paper as: Jurić F, Petranović Z, Vujanović M, Katrašnik T., Vihar R, Wang X, Duić N. Experimental and Numerical Investigation of Injection Timing and Rail Pressure Impact on Combustion Characteristics of a Diesel Engine. Energy conversion and management, 2019, doi: 10.1016/j.enconman.2019.02.039.

424

425

426

427

428

429

430

431

432

433

434

435

436

437

438

439

440

441

442

443

444

445

446

447

448

449

450

451

452

453

454

455

where $\dot{m}_{f t}$ is the fuel consumption, $f$ is the engine speed $(\mathrm{Hz}), n_{c y c l}$ is the number of cylinders that engine has, and $n_{n h}$ is the number of nozzle holes that injector has. The half outer cone angle $\gamma$, used for spray definition was calculated according to the following expression [42]:

$$
\gamma=\operatorname{arctg}\left[\frac{4 \pi \sqrt{3}}{6\left(3+0.28\left(\frac{l}{d_{n h}}\right)\right)} \sqrt{\frac{\rho_{g}}{\rho_{f}}}\right],
$$

where $l$ is the length of the nozzle, and $d_{n h}$ is the nozzle hole diameter, $\rho_{g}$ is the gas density and $\rho_{f}$ is the density of injected fuel. In Equation (23), the impact of $l$ was neglected due to its small influence on the spreading angle. Within the EL spray model, WAVE breakup model was considered [43]. The WAVE model constant $C_{2}$ was varied between 6 and 12 in single injection cases, and for the multi-injection cases it was considered 15 during the PI, and 25 during the MI period. Additionally, for the case $g$ with the multi injection strategy, the ratio between PI and MI fuel mass was not known in experimental research. This ratio was assumed the same as the ratio between the combustion areas of PI and MI under the experimental rate of heat release curve.

\section{RESULTS}

In this section, the experimental and CFD simulation results are presented. Firstly, the incylinder pressure and ROHR results of single-injection operating points are compared with the experimental results. Furthermore, for specific crank angle positions, the development of evaporated fuel and temperature field through the engine combustion chamber is described. At the end of the chapter, the results of multi-injection operating point are discussed.

\subsection{Single injection results}

Figure 4 shows the differences in in-cylinder pressure and ROHR curves obtained by the combustion model, chemical mechanism and experiment for 6 operating points (cases) with a single injection strategy. The presented ROHR is calculated for the $1 / 6^{\text {th }}$ of the cylinder bowl volume, indicating that for the entire engine, this value should be multiplied by a number of nozzle holes and number of engine cylinders.

The fuel autoignition point, or the start of combustion (SOC), is indicated by the initial departure of ROHR from the zero value. It is discernible from figures that SOC is predicted 
Cite this paper as: Jurić F, Petranović Z, Vujanović M, Katrašnik T., Vihar R, Wang X, Duić N. Experimental and Numerical Investigation of Injection Timing and Rail Pressure Impact on Combustion Characteristics of a Diesel Engine. Energy conversion and management, 2019, doi: 10.1016/j.enconman.2019.02.039.

456

457

458

459

460

461

462

463

464

465

466

467

468

469

470

471

472

473

474

475

476

477

478

479

480

481

482

483

484

485

486

487

488

489

490

491

well in the analysed case, indicating plausibility of the employed models also during the ignition delay period.

It is noticed that for cases $a, b$, and $f$, the GGPR model predicts higher peak values of ROHR in comparison with the combustion ECFM-3Z+ model and with the experimental data. This can be mostly attributed to a different combustion modelling approaches, where the turbulence fluctuations are differently described. Additionally, the ECMF-3Z+ features 3-mixing zones for the air and fuel, which lead to a more appropriate SOC and ROHR predictions in the premixed phase of combustion. In the GGPR approach, it is assumed that the reaction rates of the chemical mechanism are calculated based on mean quantities, which increases the uncertainty of a turbulent flame calculation. The high turbulent fluctuations obtained during spray injection and ignition of evaporated fuel produce the discrepancy in the ROHR results obtained for the cases fluid dynamics in Figure 4. In Equation (9) it can be noticed, that the products of mean and instantons species concentrations and chemical reaction rates are different. In the ECFM-3Z+ model, the turbulence fluctuations are considered inside the mixing model and are used for the modelling of the source term in Equation (14). For calculation of source terms in the Equation (14) for the fuel and oxygen, the mixing time-scale between 3-zones is required, which is assumed to be proportional to the turbulent time-scale given by the turbulence model.

The cases $a, b$ and $c$ have the same mass of injected fuel and injection timing but lower injection pressure as cases on their right-hand side. In the case $a$, it is noticed that the peak incylinder pressure in the premixed phase is lower for approximately 10 bar than in the case $d$, which is addressed to the lower injection pressure and lower droplet velocities. With lower droplet velocities, the spray droplets are larger and evaporate slower resulting in lower ROHR values and lower in-cylinder pressure.

For a higher rail pressure values, the rate of heat release curve exhibits higher gradients, which can be attributed to a better fuel disintegration process due to higher injection pressure, and thus higher share of evaporated fuel before the SOC. For cases $c$ and $f$, the fuel injection occurs after the piston reached TDC, which leads to the SOC after the peak motoring pressure. For these cases, differences in peak values of ROHR are less noticeable. In the ECFM-3Z+ model, the auto-ignition and laminar flame speed model are considered, which can be the reason why the ROHR predictions show a more reliable result in the SOC phase when compared with the GGPR.

From the results presented in Figure 4, it can be concluded that for the fuel injection after the TDC, the injection pressure has a lower impact on the combustion process. Furthermore, it can be concluded that both the ECFM-3Z+ and chemical mechanism results show a good agreement with the experimental data. Additionally, GGPR shows a better prediction in the 
Cite this paper as: Jurić F, Petranović Z, Vujanović M, Katrašnik T., Vihar R, Wang X, Duić N. Experimental and Numerical Investigation of Injection Timing and Rail Pressure Impact on Combustion Characteristics of a Diesel Engine. Energy conversion and management, 2019, doi: 10.1016/j.enconman.2019.02.039.

a)

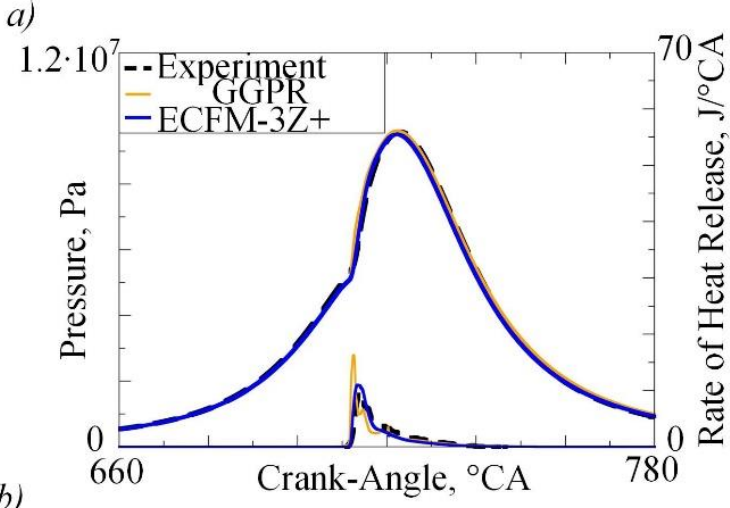

b)

c)
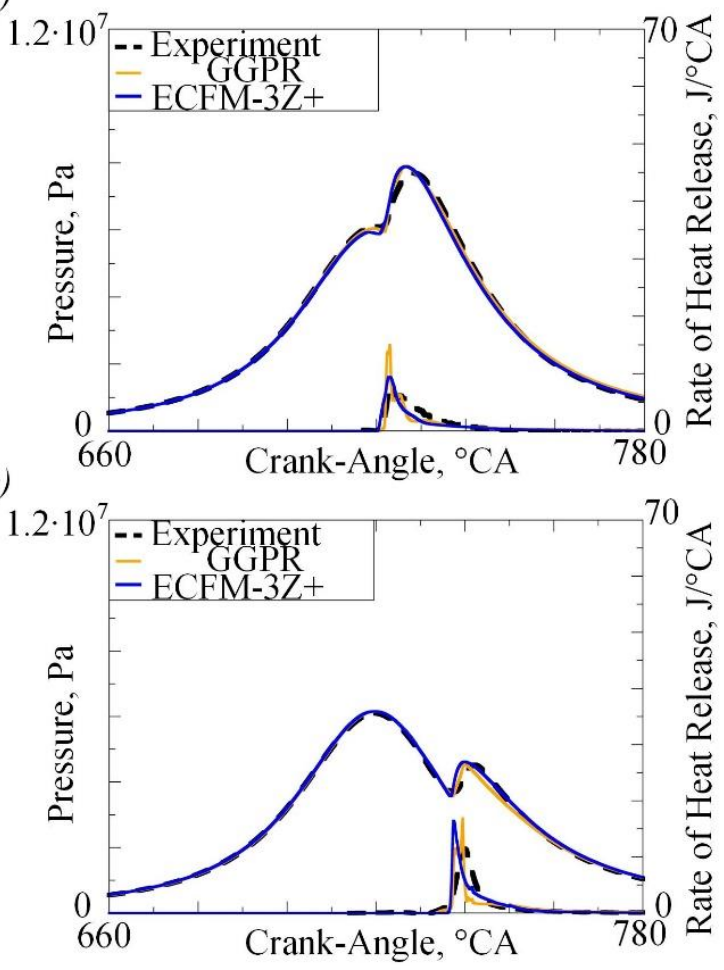

d)
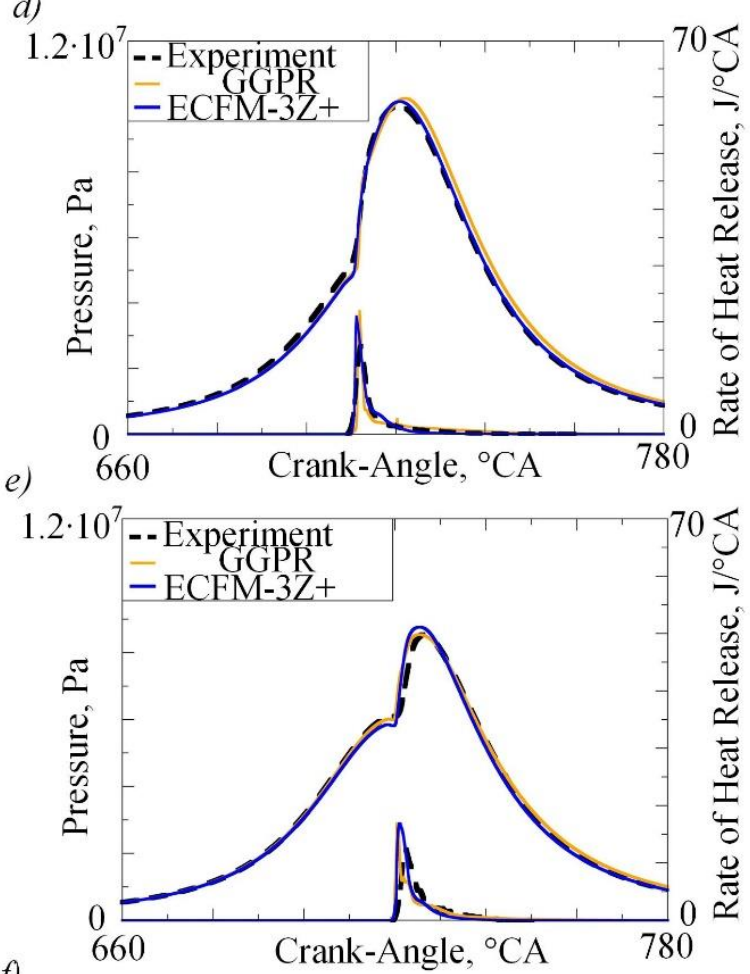

f)

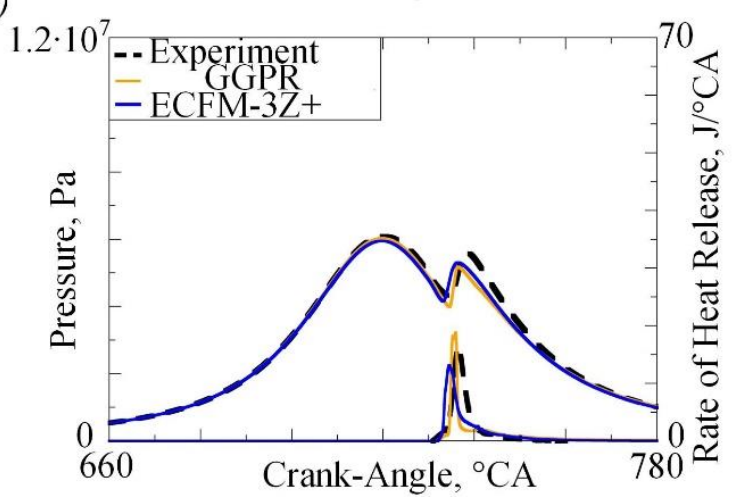

495

496

497

498

499

500

501

502

503

Figure 4 The in-cylinder pressure and rate of heat release for single injection cases defined in Table 3

In Figure 5, the injected droplet velocity is shown for case $a$. This view with six nozzle hole injections was obtained cloning the results for the $1 / 6^{\text {th }}$ of the cylinder bowl volume around the $\mathrm{z}$-axis, to envisage the actual injection process inside the whole cylinder. The droplet velocity results were obtained from the continuity equation, where the injection pressure was accelerating the droplets to the shown velocity results. 
Cite this paper as: Jurić F, Petranović Z, Vujanović M, Katrašnik T., Vihar R, Wang X, Duić N. Experimental and Numerical Investigation of Injection Timing and Rail Pressure Impact on Combustion Characteristics of a Diesel Engine. Energy conversion and management, 2019, doi: 10.1016/j.enconman.2019.02.039.

505

506

507

508

509

510

511

512

513

514

515

516

517

518

519

520

521

522
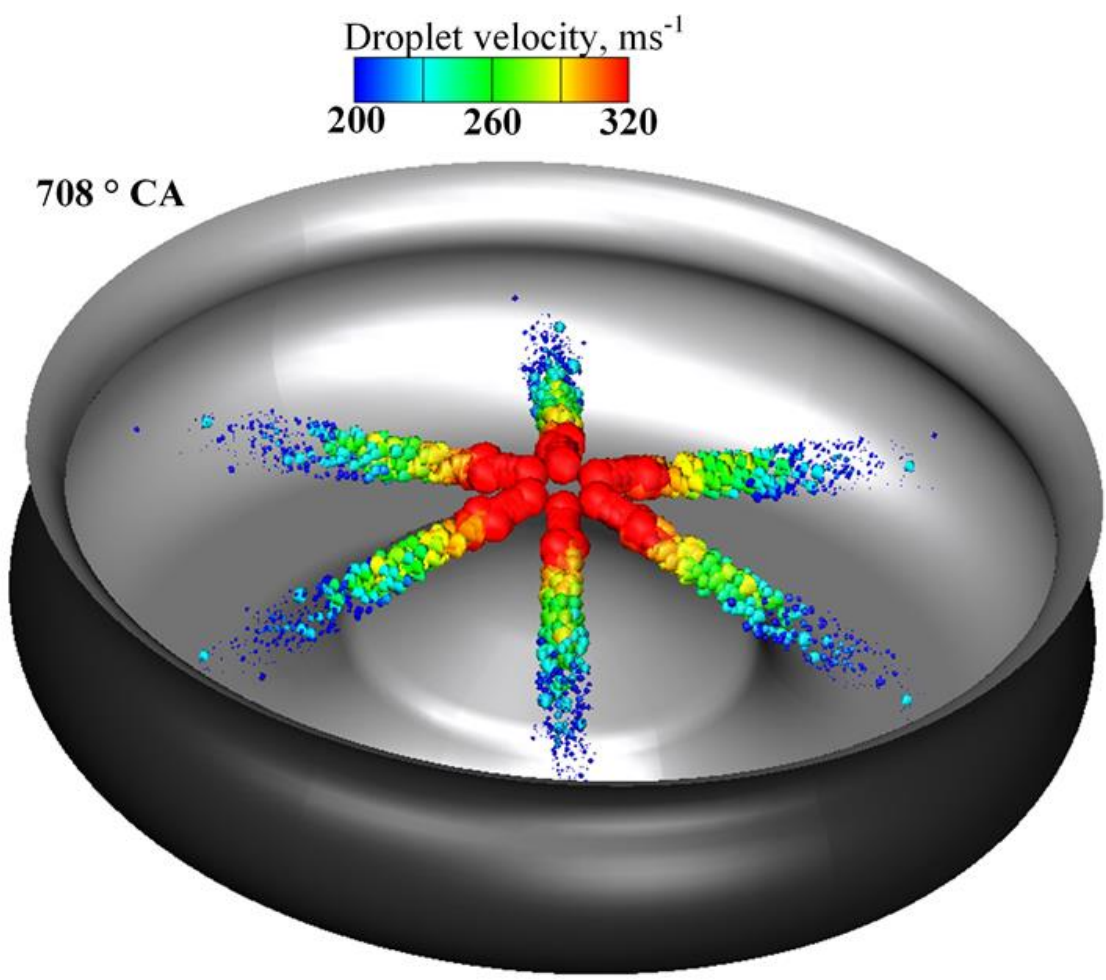

Figure 5 Injected parcel velocity for the whole cylinder of single injection case (case $a$ )

The evaporated fuel distribution for the single injection case $a$ is presented in Figure 6. The vapour fuel concentration is in direct relation to the temperature field shown in Figure 7 where the regions of lower temperature, due to the evaporation process are as well the regions of higher concentration of evaporated fuel. At $710^{\circ} \mathrm{CA}$, the injection process ends, and the initial fuel vapour is produced. At $711^{\circ} \mathrm{CA}$, the combustion process starts and the concentration of the evaporated fuel decreases. It can be noticed that the evaporated fuel is propagating towards the piston bowl where the combustion occurs with the largest share, as can be seen from temperature distribution in Figure 7. At $712^{\circ} \mathrm{CA}$, the evaporated fuel is spread in the high-temperature region which propagates its combustion. In later crank angle positions, the evaporated fuel disappears in chemical reactions acting as a reactant. The results of evaporated fuel predicted with the ECFM-3Z+ show that the evaporation process is more intensive than in GGPR. But in Figure 4, it is shown that the burning process is faster in the GGPR. That can be attributed to the auto-ignition and laminar flame speed model in ECMF-3Z+ that slows down the combustion process. 
Cite this paper as: Jurić F, Petranović Z, Vujanović M, Katrašnik T., Vihar R, Wang X, Duić N. Experimental and Numerical Investigation of Injection Timing and Rail Pressure Impact on Combustion Characteristics of a Diesel Engine. Energy conversion and management, 2019, doi: 10.1016/j.enconman.2019.02.039.

Mass fraction of evaporated fuel, -

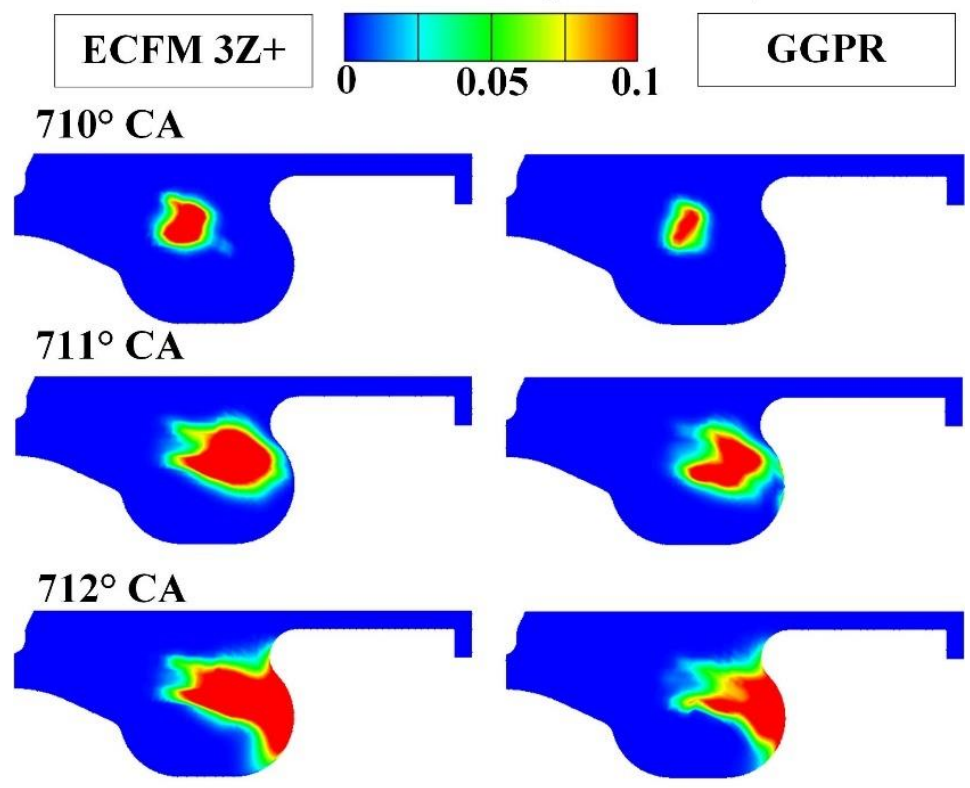

Figure 6 Temperature field for different combustion modelling approaches of single injection case (case $a$ ).

Figure 7 shows temperature fields for the case $a$, which is a representative case for analysis of calculated results for a single injection strategy. The 3D results are shown for the symmetry plane of the computational domain. The temperature field recorded at $710^{\circ} \mathrm{CA}$ clearly shows the influence of fuel injection process. The intense breakup promotes the evaporation process by enlarging the surface available for the mass transfer of the liquid fuel into the gaseous phase. The cooling of the gas phase is visible due to the evaporation process. At $717^{\circ} \mathrm{CA}$, the combustion starts and the local temperature rise is visible. For that crank angle position, it can be noticed that with the ECFM-3Z+ model the higher share of fuel is burned resulting in the larger high-temperature region characterized by the lower peak value. It can be concluded, that in ECFM-3Z+ model fuel-air mixing is better described. The peak temperatures are recorded at $724^{\circ} \mathrm{CA}$, where the maximum temperature is in a good agreement for the results obtained with both modelling approaches. 
Cite this paper as: Jurić F, Petranović Z, Vujanović M, Katrašnik T., Vihar R, Wang X, Duić N. Experimental and Numerical Investigation of Injection Timing and Rail Pressure Impact on Combustion Characteristics of a Diesel Engine. Energy conversion and management, 2019, doi: 10.1016/j.enconman.2019.02.039.

540

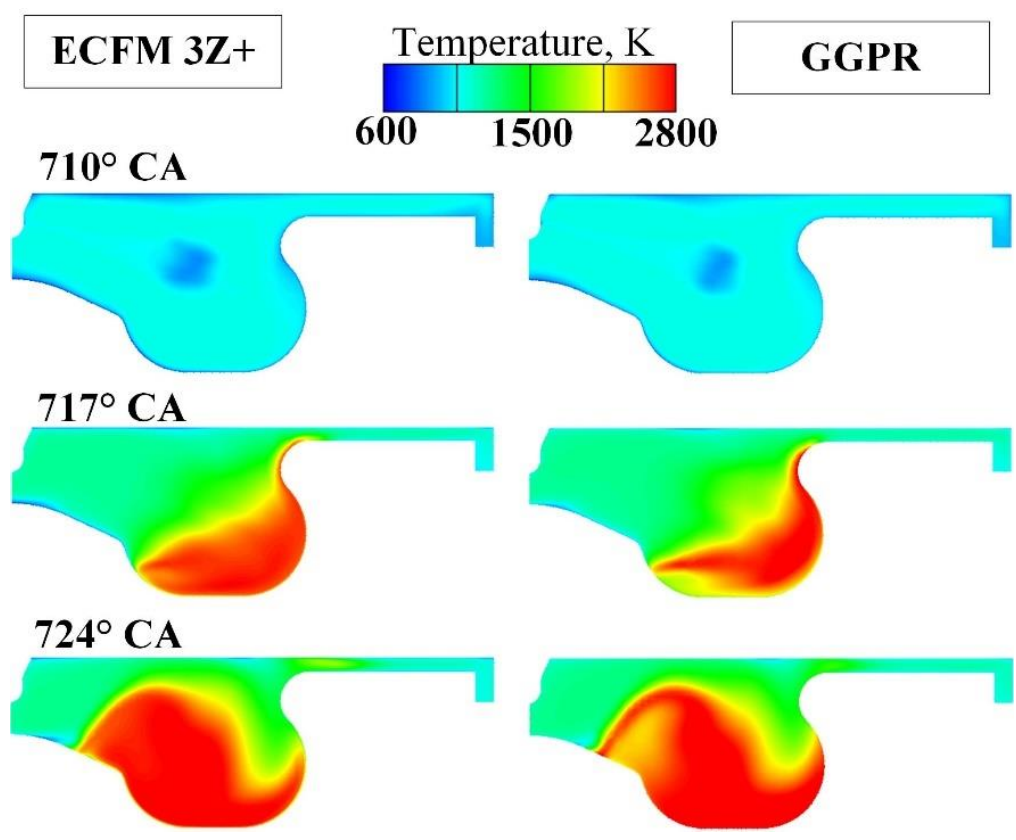

Figure 7 Temperature field for different combustion modelling approaches for operating point $a$.

\subsection{Multi-injection results}

Figure 8 shows the in-cylinder pressure results obtained by the combustion model, GGPR approach, and experimental data for the multi-injection operating point. The comparison of the experimental and calculated ROHR during the injection period for the computational domain is also shown, where the area under curves represents the accumulated released energy. The ignition of the PI fuel predicted by the ECFM-3Z+ model is occurring slightly before recorded experimental data. For the PI fuel, using the GGPR approach a higher ignition delay is noticed when compared to the experimental data. From showed results in Figure 7, it can be stated, that in the rate-controlled of combustion process, ECFM-3Z+ model shows stronger diffusion of temperature field, due to the more detailed consideration of combustion diffusion phenomena. In Equation (14) of the ECFM-3Z+ combustion model, the consideration of Sc number improves interaction with the in-cylinder flow and which can be seen in the larger hightemperature region at $717^{\circ} \mathrm{CA}$. 
Cite this paper as: Jurić F, Petranović Z, Vujanović M, Katrašnik T., Vihar R, Wang X, Duić N. Experimental and Numerical Investigation of Injection Timing and Rail Pressure Impact on Combustion Characteristics of a Diesel Engine. Energy conversion and management, 2019, doi: 10.1016/j.enconman.2019.02.039.

560

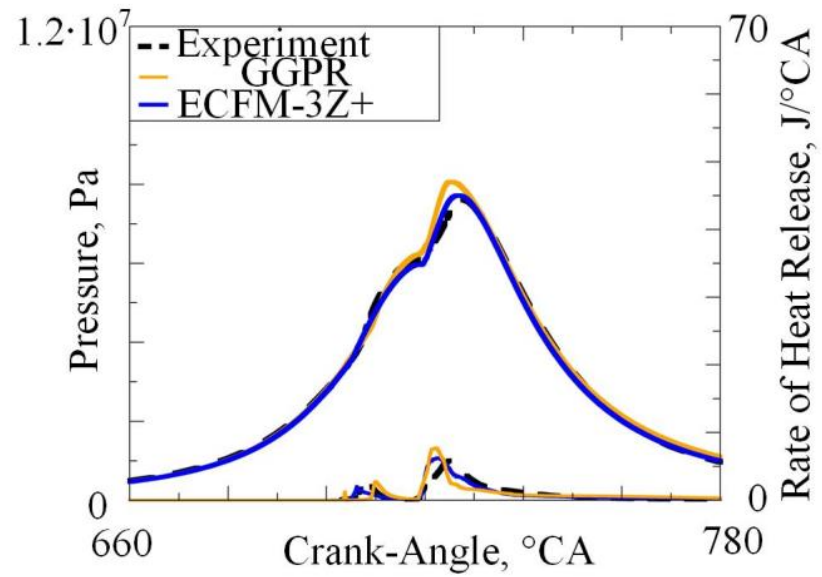

Figure 8 The mean in-cylinder pressure and the rate of heat release results obtained by experiment, GGPR and ECFM-3Z+ for multi-injection case defined in Table 4

Figure 9 shows the evaporated fuel distribution for different crank angle positions at the spray axis plane for the multi-injection case $g$. The fuel vapour is shown several crank angle degrees after $700^{\circ} \mathrm{CA}$ when the PI is finished. The concentrations of evaporated fuel predicted in ECFM-3Z+ simulations show a more intensive evaporation process during the PI. Such behaviour can be attributed to a better description of turbulence-chemistry interaction and faster ignition when comparing to the GGPR approach. This can also be seen in the ROHR curve in Figure 8 . At $703^{\circ} \mathrm{CA}$, the combustion process of the PI fuel occurs and the concentration of the evaporated fuel decreases. At later crank angle positions, the MI occurs. Compared to single injection cases faster evaporation is noticed, which can be addressed to the higher in-cylinder temperature achieved through PI combustion. Higher temperatures also accelerate chemical reactions and reduce the ignition delay of MI. Due to that, a premixed peak of MI combustion is not pronounced as in single injection cases. Such behaviour, characterised by lower temperatures and pressure increase gradients, is favourable for the engine noise and $\mathrm{NO}_{\mathrm{x}}$ emissions. In the ECFM-3Z+ approach, due to auto-ignition model and laminar flame speed model that postpone the combustion process, the overall combustion process of evaporated fuel during the spray injection is slower than in the GGPR approach. At $724^{\circ} \mathrm{CA}$, the combustion process of the MI fuel occurs and the concentration of the evaporated fuel decreases. The last remaining evaporated fuel is located in the near piston region, where the lower temperature of the piston postpones the combustion process. 
Cite this paper as: Jurić F, Petranović Z, Vujanović M, Katrašnik T., Vihar R, Wang X, Duić N. Experimental and Numerical Investigation of Injection Timing and Rail Pressure Impact on Combustion Characteristics of a Diesel Engine. Energy conversion and management, 2019, doi: 10.1016/j.enconman.2019.02.039.

Mass fraction of evaporated fuel, -

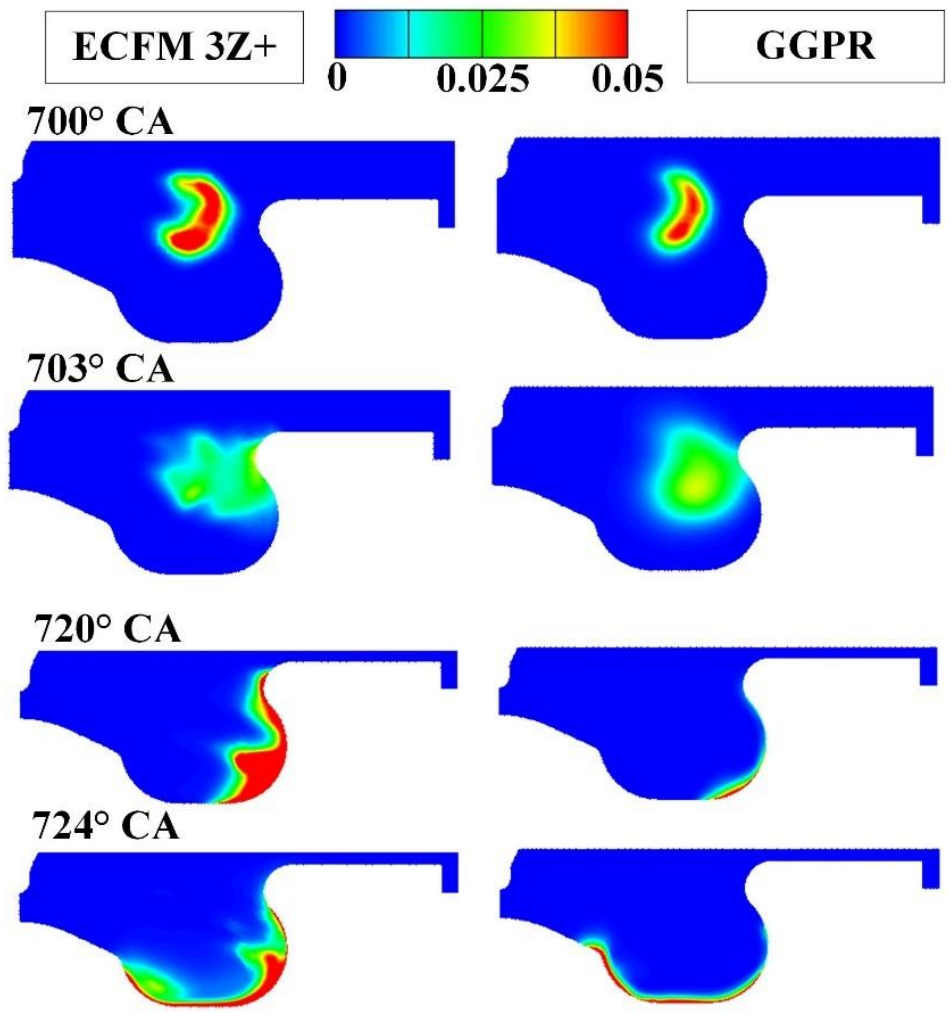

Figure 9 Temperature field for different combustion modelling approaches of the multiinjection case (case $g$ ).

In Figure 10 the temperature field for different crank angle positions of case $g$ is shown.

589 The temperature distribution at $697^{\circ} \mathrm{CA}$ shows the influence of PI where the cooling of the 590 gas phase is visible due to the lower fuel temperature and fuel evaporation. At $714^{\circ} \mathrm{CA}$, the 591 combustion of vapour fuel from the PI occurs, and the rise in temperature is visible in the combustion regions. At $717^{\circ} \mathrm{CA}$, the $\mathrm{MI}$ occurs, which is demonstrated with a lower 593 temperature in the spray region. The peak temperatures are recorded at $730^{\circ} \mathrm{CA}$, where the maximum temperature is higher for the results obtained with the GGPR approach. 
Cite this paper as: Jurić F, Petranović Z, Vujanović M, Katrašnik T., Vihar R, Wang X, Duić N. Experimental and Numerical Investigation of Injection Timing and Rail Pressure Impact on Combustion Characteristics of a Diesel Engine. Energy conversion and management, 2019, doi: 10.1016/j.enconman.2019.02.039.
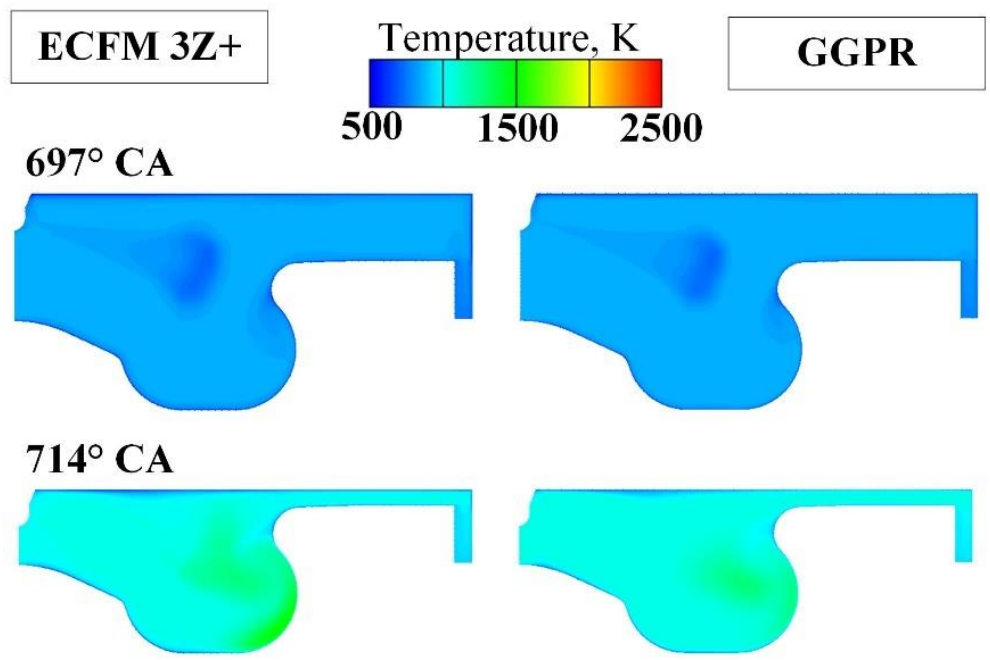

$720^{\circ} \mathrm{CA}$
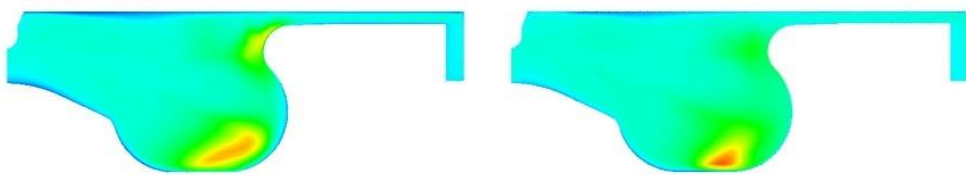

$730^{\circ} \mathrm{CA}$
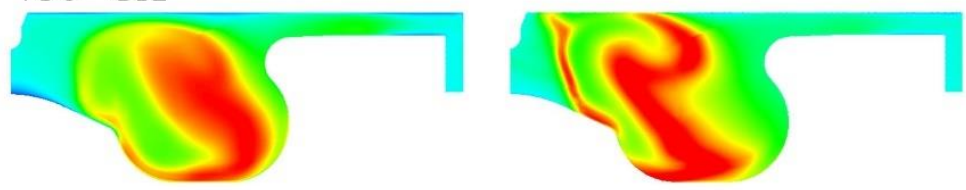

Figure 10 Temperature field for different combustion modelling approaches of the multiinjection case (case $g$ ).

\section{CONCLUSIONS}

The purpose of this paper was to present the different 3D numerical approaches, applied on the IC diesel engine, with a good trade-off between computational efficiency and modelling depth to achieve a high level of predictability. The influence of injection timing and rail pressure on combustion characteristics was investigated with the presented analysis for CFD simulations. The experimental research and diesel engine combustion simulations performed with ECFM-3Z+ and GGPR combustion modelling approaches were conducted for several injection timings showing a good prediction capability. The experimental matrix was made to show the impact of rail pressure, in-cylinder pressure, in-cylinder temperature and chemical species concentrations on the overall combustion process. Measured results of ignition delays and ROHR indicate the change of air to fuel ratio in the premixed and in the mixture-controlled combustion, which was also proved by the 3D results of simulations. Furthermore, it was

612 shown that the GGPR modelling approach is good for estimation of combustion delay and less

613 accurate in the premixed and mixture-controlled combustion. The ECFM-3Z+ modelling 
Cite this paper as: Jurić F, Petranović Z, Vujanović M, Katrašnik T., Vihar R, Wang X, Duić N. Experimental and Numerical Investigation of Injection Timing and Rail Pressure Impact on Combustion Characteristics of a Diesel Engine. Energy conversion and management, 2019, doi: 10.1016/j.enconman.2019.02.039.

614 approach, on the other hand, shows a good agreement of the mean in-cylinder pressure and 615 ROHR also in the late combustion phase. This can be addressed to usage of the auto-ignition 616 and the laminar flame speed models within this approach. Both combustion modelling 617 approaches were validated on the operating point with a multi-injection strategy, and a good 618 agreement with the experimental results was achieved, especially for the ECFM-3Z+ case. In 619 the rate-controlled and late phase of the combustion process, the ECFM-3Z+ model shows a 620 stronger diffusion of the temperature field, due to a more detailed consideration of combustion diffusion phenomena. It can be concluded that for the fuel injection after the TDC, the injection pressure has a lower impact on the combustion process.

Acknowledgements

624

625

626

627

628

629

630

631

632

633

634

635

636

637

638

639

640

641

642

643

644

645

646

647

648

649

650

This work has been fully supported by Croatian Science Foundation under the project IP-201606-1488. Authors would also wish to thank the CFD development group at AVL-AST, Graz, Austria, for their support and technical discussions during the model development.

\section{References}

[1] Chong HS, Park Y, Kwon S, Hong Y. Analysis of real driving gaseous emissions from light-duty diesel vehicles. Transp Res Part D Transp Environ 2018;65:485-99. doi:10.1016/J.TRD.2018.09.015.

[2] Katrašnik T. Hybridization of powertrain and downsizing of IC engine - A way to reduce fuel consumption and pollutant emissions - Part 1. Energy Convers Manag 2007;48:1411-23. doi:10.1016/j.enconman.2006.12.004.

[3] https://www.fuelseurope.eu/knowledge/how-refining-works/diesel-gasoline-imbalance n.d.

[4] Petranovic Z, Edelbauer W, Vujanović M, Priesching P, Tatschl R, Duić N. Modeling of Reactive Spray Processes in DI Diesel Engines. SAE Tech Pap Ser 2017.

[5] Kılkış Ş, Krajačić G, Duić N, Rosen MA, Al-Nimr MA. Advancements in sustainable development of energy, water and environment systems. Energy Convers Manag 2018;176:164-83. doi:10.1016/J.ENCONMAN.2018.09.015.

[6] Petranović Z, Edelbauer W, Vujanović M, Duić N. Modelling of spray and combustion processes by using the Eulerian multiphase approach and detailed chemical kinetics. Fuel 2017;191:25-35. doi:10.1016/j.fuel.2016.11.051.

[7] Divekar PS, Chen X, Tjong J, Zheng M. Energy efficiency impact of EGR on organizing clean combustion in diesel engines. Energy Convers Manag 2016;112:369-81. doi:10.1016/j.enconman.2016.01.042.

[8] Guo C, Song Y, Feng H, Zuo Z, Jia B, Zhang Z, et al. Effect of fuel injection characteristics on the performance of a free-piston diesel engine linear generator: CFD 
Cite this paper as: Jurić F, Petranović Z, Vujanović M, Katrašnik T., Vihar R, Wang X, Duić N. Experimental and Numerical Investigation of Injection Timing and Rail Pressure Impact on Combustion Characteristics of a Diesel Engine. Energy conversion and management, 2019, doi: 10.1016/j.enconman.2019.02.039.

simulation and experimental results. Energy Convers Manag 2018;160:302-12. doi:10.1016/j.enconman.2018.01.052.

[9] Petranović Z, Sjerić M, Taritaš I, Vujanović M, Kozarac D. Study of advanced engine operating strategies on a turbocharged diesel engine by using coupled numerical approaches.

Energy

Convers

Manag

2018;171:1-11.

657

658

659

660

661

662

663

664

665

666

667

668

669

670

671

672

673

674

675

676

677

678

679

680

681

682

683

684

685

686

687 doi:10.1016/j.enconman.2018.05.085.

[10] Zhao F, Yang W, Zhou D, Yu W, Li J, Tay KL. Numerical modelling of soot formation and oxidation using phenomenological soot modelling approach in a dual-fueled compression ignition engine. Fuel 2017;188:382-9. doi:10.1016/j.fuel.2016.10.054.

[11] Petranović Z, Bešenić T, Vujanović M, Duić N. Modelling pollutant emissions in diesel engines, influence of biofuel on pollutant formation. J Environ Manage 2016:1-9. doi:10.1016/j.jenvman.2017.03.033.

[12] Anand K, Reitz RD. Exploring the benefits of multiple injections in low temperature combustion using a diesel surrogate model. Fuel 2016;165:341-50. doi:10.1016/j.fuel.2015.10.087.

[13] Sremec M, Taritaš I, Sjerić M, Kozarac D. Numerical Investigation of Injection Timing Influence on Fuel Slip and Influence of Compression Ratio on Knock Occurrence in Conventional Dual Fuel Engine. J Sustain Dev Energy, Water Environ Syst 2017;5:51832. doi:10.13044/j.sdewes.d5.0163.

[14] Baleta J, Mikulčić H, Vujanović M, Petranović Z, Duić N. Numerical simulation of urea based selective non-catalytic reduction deNOx process for industrial applications. Energy Convers Manag 2016;125:59-69. doi:10.1016/j.enconman.2016.01.062.

[15] Taghavifar H, Khalilarya S, Jafarmadar S. Engine structure modifications effect on the flow behavior, combustion, and performance characteristics of di diesel engine. Energy Convers Manag 2014;85:20-32. doi:10.1016/j.enconman.2014.05.076.

[16] Li XR, Zhou HQ, Zhao LM, Su L, Xu H, Liu FS. Effect of split injections coupled with swirl on combustion performance in DI diesel engines. Energy Convers Manag 2016;129:180-8. doi:10.1016/j.enconman.2016.09.011.

[17] Abdul Gafoor CP, Gupta R. Numerical investigation of piston bowl geometry and swirl ratio on emission from diesel engines. Energy Convers Manag 2015;101:541-51. doi:10.1016/j.enconman.2015.06.007.

[18] Hossain AK, Smith DI, Davies PA. Effects of engine cooling water temperature on performance and emission characteristics of a compression ignition engine operated with biofuel blend. J Sustain Dev Energy, Water Environ Syst 2017;5:46-57. doi:10.13044/j.sdewes.d5.0132.

[19] Zhang Q, Hao Z, Zheng X, Yang W. Characteristics and effect factors of pressure oscillation in multi-injection DI diesel engine at high-load conditions. Appl Energy 
Cite this paper as: Jurić F, Petranović Z, Vujanović M, Katrašnik T., Vihar R, Wang X, Duić N. Experimental and Numerical Investigation of Injection Timing and Rail Pressure Impact on Combustion Characteristics of a Diesel Engine. Energy conversion and management, 2019, doi: 10.1016/j.enconman.2019.02.039.

688

689

690

691

692

693

694

695

696

697

698

699

700

701

702

703

704

705

706

707

708

709

710

711

712

713

714

715

716

717

718

719

720

721

722

723

724

2017;195:52-66. doi:10.1016/j.apenergy.2017.03.048.

[20] Lazaroiu G, Pană C, Mihaescu L, Cernat A, Negurescu N, Mocanu R, et al. Solutions for energy recovery of animal waste from leather industry. Energy Convers Manag 2017;149:1085-95. doi:10.1016/j.enconman.2017.06.042.

[21] Cernat A, Pana C, Negurescu N, Lazaroiu G, Nutu C. Aspects of the animal fat use at the diesel engine fuelling. Proc Univ Power Eng Conf 2015:1-6. doi:10.1109/UPEC.2015.7339917.

[22] Zhao H. Advanced Direct Injection Combustion Engine Technologies and Development - Volume 2: Diesel Engines. 2009. doi:10.1533/9781845697457.

[23] Hasse C, Barths H, Peters N. Modelling the Effect of Split Injections in Diesel Engines Using Representative Interactive Flamelets. SAE Tech Pap Ser 1999. doi:10.4271/199901-3547.

[24] EN 5902013AC2014 Automotive fuels - Diesel - Requirements and test methods 2014;1. doi:http://www.sciencedirect.com/science/article/pii/S0045782504000313.

[25] Liu S, Hewson JC, Chen JH, Pitsch H. Effects of strain rate on high-pressure nonpremixed n-heptane autoignition in counterflow. Combust Flame 2004;137:320-39. doi:10.1016/j.combustflame.2004.01.011.

[26] Zhang $\mathrm{C}, \mathrm{Wu} \mathrm{H}$. The simulation based on CHEMKIN for homogeneous charge compression ignition combustion with on-board fuel reformation in the chamber. Int $\mathbf{J}$ Hydrogen Energy 2012;37:4467-75. doi:10.1016/j.ijhydene.2011.11.104.

[27] AVL FIRE Documentation 2017. Graz: 2017.

[28] Wu X, Deng J, Cui H, Xue F, Zhou L, Luo F. Numerical simulation of injection rate of each nozzle hole of multi-hole diesel injector. Appl Therm Eng 2016;108:793-7. doi:10.1016/j.applthermaleng.2016.07.136.

[29] Hanjalić K, Popovac M, Hadžiabdić M. A robust near-wall elliptic-relaxation eddyviscosity turbulence model for CFD. Int J Heat Fluid Flow 2004;25:1047-51. doi:10.1016/j.ijheatfluidflow.2004.07.005.

[30] Crowe CT, Schwarzkopf JD, Sommerfeld M, Tsuji Y. Multiphase Flows with Droplets and Particles. Taylor \& Francis Group; 2012.

[31] Ferziger JH, Peric M. Computational Methods for Fluid Dynamics. 2002. doi:10.1016/S0898-1221(03)90046-0.

[32] Schiller L, Naumann AZ. VDI 77 1933:318-20.

[33] Cunningham E. On the Velocity of Steady Fall of Spherical Particles through Fluid Medium. Proc R Soc A Math Phys Eng Sci 1910;83:357-65. doi:10.1098/rspa.1910.0024.

[34] Liu AB, Mather D, Reitz RD. Modeling the Effects of Drop Drag and Breakup on Fuel Sprays. SAE Tech Pap Ser 1993;298:4-7. 
Cite this paper as: Jurić F, Petranović Z, Vujanović M, Katrašnik T., Vihar R, Wang X, Duić N. Experimental and Numerical Investigation of Injection Timing and Rail Pressure Impact on Combustion Characteristics of a Diesel Engine. Energy conversion and management, 2019, doi: 10.1016/j.enconman.2019.02.039.

[35] Colin O, Benkenida A. The 3-zones Extended Coherent Flame Model (ECFM3Z) for computing premixed/diffusion combustion. Oil Gas Sci Technol 2004;59:593-609. doi:10.2516/ogst:2004043.

[36] Payri F, Luján JM, Martín J, Abbad a. Digital signal processing of in-cylinder pressure for combustion diagnosis of internal combustion engines. Mech Syst Signal Process 2010;24:1767-84. doi:10.1016/j.ymssp.2009.12.011.

[37] Rašić D, Vihar R, Žvar Baškovič U, Katrašnik T. Methodology for processing pressure traces used as inputs for combustion analyses in diesel engines. Meas Sci Technol 2017. doi:doi.org/10.1088/1361-6501/aa5f9e.

[38] AVL manual: Theory AVL BOOST. 2011.

[39] Prah I, Katrašnik T. Application of Optimization Techniques to Determine Parameters of the Vibe Combustion Model. J Mech Eng 2009;55:715-26.

[40] Tatschl R. Appendix 3D-CFD Simulation of IC-Engine Flow, Mixture Formation and Combustion with AVL FIRE. vol. 1542. 2012. doi:10.1007/978-3-642-14094-5.

[41] Popovac M, Hanjalic K. Compound Wall Treatment for RANS Computation of Complex Turbulent Flows and Heat Transfer. Flow, Turbul Combust 2007;78:177-202. doi:10.1007/s10494-006-9067-x.

[42] Kenneth Kuan-Yun Kuo RA. Applications of Turbulent and Multi-Phase Combustion. 2012. doi:10.1002/9781118127575.

[43] Liu AB, Mather D, Reitz RD. Modeling the Effects of Drop Drag and Breakup on Fuel Sprays 1993. doi:10.4271/930072. 